\title{
Кинетические закономерности УДК 678-01 кристаллизации металлополимерных композитов на основе меди и полиэтилена низкой плотности
}

\section{Kinetic regulations of crystallization of metal-polymer composites based on copper and low density polyethylene}

\section{Х. В. Аллахвердиева, Н. Т. Кахраманов}

Институт полимерных материалов

Национальной АН Азербайджана, г. Сумгайыт
Kh. V. Allakhverdieva, N. T. Kakhramanov

Institute of Polymer Materials

of the Azerbaijan National Academy of Sciences,Sumgayit city

Поступила в редакцию 16.12.2019, принята к печати 06.03.2020

\section{Абстракт}

Приводятся результаты исследования влияния концентрации мелкодисперсной меди на механизм и закономерность изменения зависимости удельного объёма от температуры в интервале $25-180^{\circ} \mathrm{C}$. Путем экстраполяции верхней и нижней ветви дилатометрической кривой найдены приблизительные значения температуры стеклования композитов. Методом ступенчатой дилатометрии найдена температура фазового перехода первого рода композитов, которая изменяется в зависимости от концентрации меди в составе полиэтилена низкой плотности. Определена зависимость свободного удельного объёма от температуры. Показано, что увеличение концентрации меди в составе полиэтилена низкой плотности сопровождается закономерным снижением свободного объёма полимерной матрицы. В координатах Аврами исследованы кинетические закономерности процесса изотермической кристаллизации в области фазового перехода первого рода. Установлено, что с увеличением степени наполнения полимерной матрицы механизм кристаллизации из сферического (трёхмерного) типа роста кристаллических образований переходит в пластинчатый (двухмерный) при непрерывном образовании центров кристаллизации.

\section{Abstract}

The results of the study of the effect of the finely dispersed copper concentration on the mechanism and regularity of the change in the dependence of the specific volume on temperature in the range of $25-180^{\circ} \mathrm{C}$ are presented. By extrapolating the upper and lower branches of the dilatometric curve, approximate values of the glass transition temperature of the composites are found. The method of step dilatometry was used to find the temperature of the first order phase transition of composites, which varies depending on the concentration of copper in the composition of low density polyethylene. It is shown that an increase in the concentration of copper in the composition of low density polyethylene is accompanied by a regular decrease in the free volume of the polymer matrix. In the Avrami coordinates, the kinetic regularities of the process of isothermal crystallization in the region of the first-order phase transition have been studied. It has been established that with an increase in the degree of filling of the polymer matrix, the crystallization mechanism from a spherical (three-dimensional) type of growth of crystalline formations passes into a lamellar (two-dimensional) type with the continuous formation of crystallization centers.

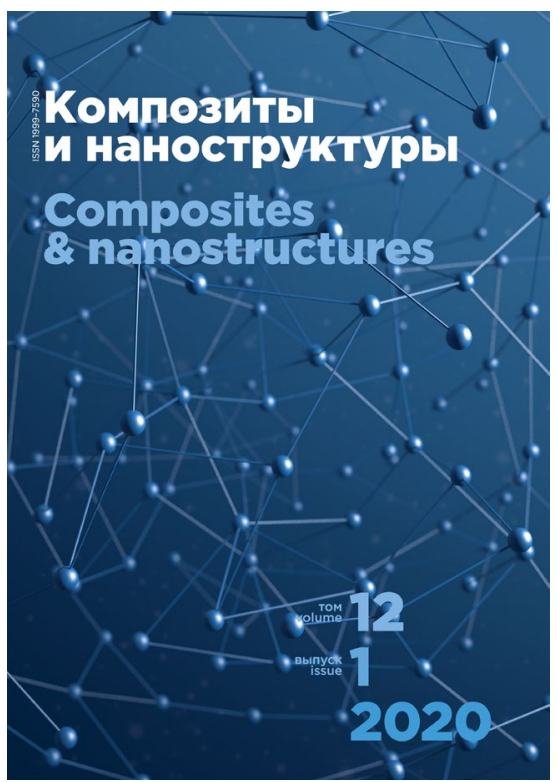

